\title{
Urban regeneration and smart city according to EU strategies: an urban distribution center in city logistics
}

\author{
P. Panuccio, L. Amodeo, P. D’Agostino, D. Lamari \\ \& T. Scattarreggia \\ DIIES - Dipartimento di Ingegneria dell'Informazione, \\ delle Infrastrutture e dell'Energia Sostenibile, \\ Università Mediterranea di Reggio Calabria, Italy
}

\begin{abstract}
This paper focuses on sustainable mobility city planning as a process that innovates and develops cities.

The indications laid down by the European Union (UE) urge us to review urban spaces in order to transform degraded areas into smart areas and, therefore, restart a process of rebalancing and sustainability, with the goal of transforming cities into smart cities. The planning activity supports the social, economic, and technological change processes. The regeneration of disused areas creates opportunities for sustainable growth.

This paper presents the issue of urban regeneration. A project of an urban distribution center, in a city logistics system, is designed for a disused railway area, located near the harbour in Reggio Calabria. The case study has tested the application of a model of urban regeneration, through the design of innovation zones, according to European Union strategies to encourage the development of a smart city.
\end{abstract}

Keywords: urban planning, smart city, sustainability, city logistics, urban distribution center. 


\section{Planning in Europe}

\subsection{The European Spatial Development Perspective}

In recent years, Europe has been working on urban space in order to transform cities into sustainable cities.

Planning offers the possibility to develop and transform a city into a modern and attractive city.

The European Spatial Development Perspective (ESDP) is a framework of planning policies that operate across Europe (EU), to develop principles of sustainable development and balanced urban systems. ESDP defines common objectives for spatial development; it is organized in two parts: the contribution of the spatial development policy as a new dimension of European policy; and the trends, opportunities and challenges facing the territory of the EU [1].

The ESDP introduces four major areas that interact and exert considerable pressure on the spatial development of the European Union: the development of urban areas; the development of rural areas; the transport; and the natural and cultural heritage.

\subsection{Urban planning in Italy}

Urban planning in Italy supports land use: it prescribes constraints; organizes and coordinates the actions; authorizes to build volumes, build infrastructure, provides spaces of services to the community.

The general plan is the planning product that authorizes the city to extend its surfaces [2]. The zoning dimensioned the urban plan. Behind each screen, graphic sign to identify the type of area and the norm that regulates its uses lies the design decision for the development of the city.

The dimensioning of the compartments, zoning, the application of standards, the intended use, the implementing technical standards, result from the calculation of the surfaces and the number of inhabitants. However, the assignment of the urban area is an important choice, because it destines the city to its future; decide its use; adjusts the procedures for implementation of constructions; assigns roles and functions to the territory.

Italian legislation about planning is characterized by three historical periods. The first period, from 1900 to 1941, was regulated without laws, only some regulations of ornate and aesthetics. The second period, from 1942 to 1989, is the one in which the design of the master plan determined the development of the city. The third period, from 1990 until today, started delegating to the regions the legislative and administrative power of territorial government. This is the period of the complex process of transition towards a new culture of planning [3].

The great delay of planning in Italy derived from the cutting respect to the quantitative approaches. In other EU countries the use of models to forecast the developing and to check the scenarios are a current practice: from national planning to local planning [4]. 
Urban planning and legal certainty are insufficient for the management of the territories. From induction social, have only justified a gigantic enrichment of certain social groups with the transfer to private, of the right land use that has ceased to be a common good.

Planning has taken a decisive role in the period of reconstruction and urban sprawl; it has developed decisive tools for the functional organization of the cities and has addressed the organizational process for the development of the territories $[5,6]$. The enormous increase of volumes has given rise to urban inconsistencies.

\section{From expansion to transformation}

\subsection{Urban regeneration}

Over the years the city has changed its constituent canons. The city, from a place of social life, has become a space to be used to take advantage of the infrastructure and services. This mentality has generated degradation, disorder, waste, lack of resources, poor services. It shaped to a new model of city that determined the processes of urban sprawling.

The techniques employed for planning the reconstruction of the city during the second period of urbanism, have not evolved at the same rhythm, of the economic and social development. Today the areas appear strongly unbalanced, denaturalized, defrauded by their characteristics.

It is urgent to define a new model of urban development, structured on a coherent and organic policy, with multi-level relationships, in which cities play the dual role of policy takers and policy makers [7].

The European Union encourages the city to recover their cultural identities and their territorial heritage in order to reorganize their space, according to new principles of logical development [1]. The not used areas abandon their original functions, offer themselves as an opportunity to reengineer functions. The new functions could be adapted to current needs and cause opportunities for new synergies between public, private and social community.

In order to regenerate an abandoned site it is not sufficient to assign a new destination of use. The real success factor for the revitalization of a place is the choice of an appropriate role, making it possible to become driving force of development, adapting to the limited resources available.

\subsection{Urban sprawl}

The theme of the land consumption inside planning is crucial. The soil is an indispensable resource for the vital balance of the community. The city can no longer consume land to realize its projects, either because it has few open areas available, either because it has already been built and the amount of surfaces in a state of neglect.

The growth model of the last decades, in which the built volumes invaded every space and at the same time, in its interior, has expanded the areas of 
degradation, up to eroding the quality of the territories, is to heal. The waste of land, the sale of the works already incorporated in the urban tissues, the underutilization of infrastructure, can no longer be sustained. The city will have to maintain an adequate level of functional urban mixed to ensure its development; activate redevelopment widespread; enhance resources; be energy efficient, sustainable, smart [8].

\subsection{Smart growth}

Smart growth is a term that expresses a positive concept. It clarifies the difference between the growth and development. The growth has resulted in cities consumption of soil and an irreverent use of resources, aiming to maximize the profits. The development is linked to sustainable design, more attentive to the balanced use of resources, to promote and transform the assets, individual elements of value, in territorial heritage, qualifying capital belonging to the public. Smart growth (SG) ensures integrated systemic, and proactive development of territories. SG, by reinvesting in existing infrastructure, encourages development that serves the economy, the community and the environment. In direct response to the effects of urban sprawl, is using creative strategies to develop in ways that preserve natural lands and critical environmental areas, protect water, air etc.

Smart growth is based on set of ten basic principles, among which are provided the more interesting ones. Mix land uses; take advantage of compact building design; create a range of housing opportunities and choices; create walkable neighborhoods; preserve open space; provide a variety of transportation choices; make development decisions predictable; encourage community and stakeholder collaboration in development decisions $[9,10]$.

\section{The role of common goods of the public areas in the $\mathbf{E U}$}

The city offers a wide variety of services and facilities. Urban planning considers the smart growth cities as the system of opportunities [11-13]. This trend of planning as different from that currently in use, which sizes the territory by applying indexes and forcing builders to comply with the minimum standard. The optimization of the good service becomes quality objective of the strategic plan of the city.

\subsection{The problem of the areas for the historical services}

In Italy, the areas destined for public services are still regulated by urban standards provided by the Ministerial Decree (DM) n.1444 of 1968. The DM fixed minimal surfaces to be allocated in the cities areas for education (nursery, kindergarten, elementary school, middle school); equipment for areas of common interest (religious, cultural, social welfare, health, administrative); areas for public parks, for games and sport; areas for public parking.

Specific requirements are directly related to municipal planning instruments, indicating the possible transformations, in line with the minimum standards set 
by the DM. The interventions of new construction and/or extension or conversion of the existing, are guided by the rules governing the possible urban actions in municipality.

In Europe, the problem of the obligation of minimal surfaces for the construction of public services, is interconnected with the project actions. It is believed that the open spaces ensure adequate surfaces to equip and provide services, cities. Territorial areas ensure adequate social welfare and quality of life to the citizens. The prospect of a sustainable design is inherent in the construction of the works. These compute that space needs to be allocated to services for the community [14].

\subsection{The problem of the areas for the new generation services}

The new generation services indicate the needs appropriate to today's society. Today cities are obliged to implement a smart prospect, to bring attention to the development of technological innovation; infrastructure transport and mobility; rebalancing of sustainable urban.

The focus is on how cities are searching new paths towards sustainable growth.

The measurement of city performance is one of the critical ways in which we can assess the complexity of urban change, and judge which approaches are successful or not.

The smartness indices developed at European level assess the level of smart growth in European cities. The patterns of articulation multidimensional adopted by several European countries, for the international analysis of urban performance, are similar. There is synthetic index computed on the size characteristic of the smart cities, considered by the EU related to the six areas of economy, living, environment, mobility, people and governance.

The mobility dimension collects indicators that measure the adaptability of urban systems to contain the negative impacts of congestion. Local and international accessibility are important aspects of smart mobility as well as the availability of ICT and modern and sustainable transport system.

\subsection{Public services for mobility}

Approximately $70 \%$ of the European population lives in cities.

As published in the report of the Freight Leaders Council (FLC [15]) costs related to traffic congestion in Italy amount to about nine billion euro per year. Freight transport in urban areas amounts to about 606 million tons per year, $48.8 \%$ of national road haulage [15-17].

Challenges promoting Europe to cities, ever more focusing on the development of infrastructure services in urban areas, aim to integrate communication technologies in the system of sustainable urban transport, in respect of the flagship initiatives of the Europe 2020 Strategy and the principles of the urban agenda of interoperability and harmonization of technological choices.

The main themes for the city are: local public transport for passengers and city logistics for freight. 


\subsubsection{Local public transport}

$70 \%$ of trips in Italian cities are made with a private car.

Urban mobility is one of the areas that has the highest level of waste [18]. There is a need of optimizing the modality of use of the transport. For some years, the European Union is working to Strategic Policies, to indicate and coordinate actions that induce cities to design and implement models of integrated between the public, private, business and commercial operators. It is believed that this is a crucial aspect for innovating the city. The design of an efficient system of urban mobility is a vital component to the realization of smart city.

The valorization of resources in the area, depends also on mobility dimension, intended both as local and international accessibility, redesigned with efficient network systems. The indicators mentioned in the report of iCity Rate for the ranking of Italian smart cities, classified in the down part of EU the Italian urban areas [16].

\subsubsection{City logistics}

The rationalization of the mobility of goods in metropolitan areas helps to reduce costs weighing on companies, reducing their competitiveness, besides having a negative impact on the city, for congestion, pollution, loss of profit.

Freight transport in urban areas requires coordination between actors involved, in order to create a platform and an interface to integrate all the information concerning the delivery of goods in the city and therefore make more immediate and easy exchange of such information.

The logistic analysis of the last mile for the final distribution that connects the producer with the consumer, place the city logistics in a valid context for the definition of the smart city $[19,20]$.

Among the proposed solutions for the rationalization of freight transport in the city, is the recovery disused areas. Almost every town has public buildings of strategic importance, to the state abandoned, that can become new strategic poles. Such as the case of urban distribution center (UDC) [21].

The UDC shapes a multi-level scheme in the urban freight distribution process, which allows freight to be carried by means of larger vehicles outside the city and, after the transhipment, by means of smaller and less polluting vehicles inside the city $[22,23]$. The UDC is the breaking point of the load that fits between the producer and the final customer, adopted by several European countries [24].

\section{Reggio Calabria}

A first proposal for the location of the urban distribution center, as a focus of the city logistics system for Reggio Calabria, is discussed. The proposal is coordinated with the analysis developed in previous works regarding the demand and the supply for freight transport in the city of Reggio Calabria $[22,23,25,26]$. 


\subsection{The Master Plan of Reggio Calabria}

The planning instrument authorizing possible interventions in the municipality of Reggio Calabria, is the Master Plan adopted in 1975.

The urban design of the Master Plan in force, drawn up in 1970 by the architect Quaroni, organized the territorial system based on three main guideline developments. The first indicated the prospect of a city directional, residential and tourist area, to be extended along the direction of expansion to the North. The second focused attention on consolidated urban areas of the central area, indicating restructuring and regeneration of the existing buildings. The third direction zone for industrial and production activities, oriented along the south. The expansion areas and residential areas intended for public services, were located in the hills, to preserve the coastline and foresaw a system of longitudinal roads.

The city, however, followed the impulse of uncontrolled and autonomous choices. The interventions, both public and private, have been made following the logic of an increasingly monocentric city. The road network, which was the supporting structure in the master plan, has not been carried out, except for a short distance; the buildings sprawled everywhere and have invaded the territory.

On 14 December 2011, the City Council adopted the preliminary document of Structural Plan City (PSC) where many have not considered the issue of city logistics.

Today, the municipal area is made up of a densely urbanized coastline and numerous small hilly and mountainous areas districts. The densification of building has reached a loading capacity on the territory beyond sustainable levels. The law of April 7, 2014 established Reggio Calabria as a Metropolitan City; that has given the city an important decisive role for the development of the territory. The goal was to identify the city with unique requirements that could become nodes, with strategic role, of a system to the national grid.

\subsection{Sustainable city}

The analysis of the current state of the city highlights several weaknesses. Several types of degradation, from the physical, ecological environmental, social and economic, to the urban, are witness to the instability that the territory is bearing, appealing to a great capacity for resilience. Improper constructions and unplanned urban areas, have deleted the cultural identity and have determined extraneous urban morphologies, few services and public spaces.

To recover a state of balance and enhance existing resources, it is essential to outline strategies in order to requalify the urban tissues. In the light of the principles of sustainable development, the strategic plan for the metropolitan city, according to the demands of the EU, must aim at achieving the balanced and sustainable development of the territory. The strategic plan must have the objective to preserve and enhance the diversity of resources activating the Biodiversity Strategy [1]. 


\subsection{Services to the historic area between the two rivers}

The historic center of the city is developed like a chessboard with the main road axis parallel to the coastline. The central area is bounded by geographical boundaries; the sea on one side; the Annunziata and the Calopinace Fiumare, North and South side respectively; the dimension line of hills marks the high zone. Historically, the city has concentrated every type of service in the center. Physical signs imprinted on the territory, have contributed to the decision to concentrate assets within the geographical walls.

The expansion which has taken place over time has made the assets increasingly congested and inadequate, for the over populated areas and not enough to satisfy the needs of the peri-urban areas.

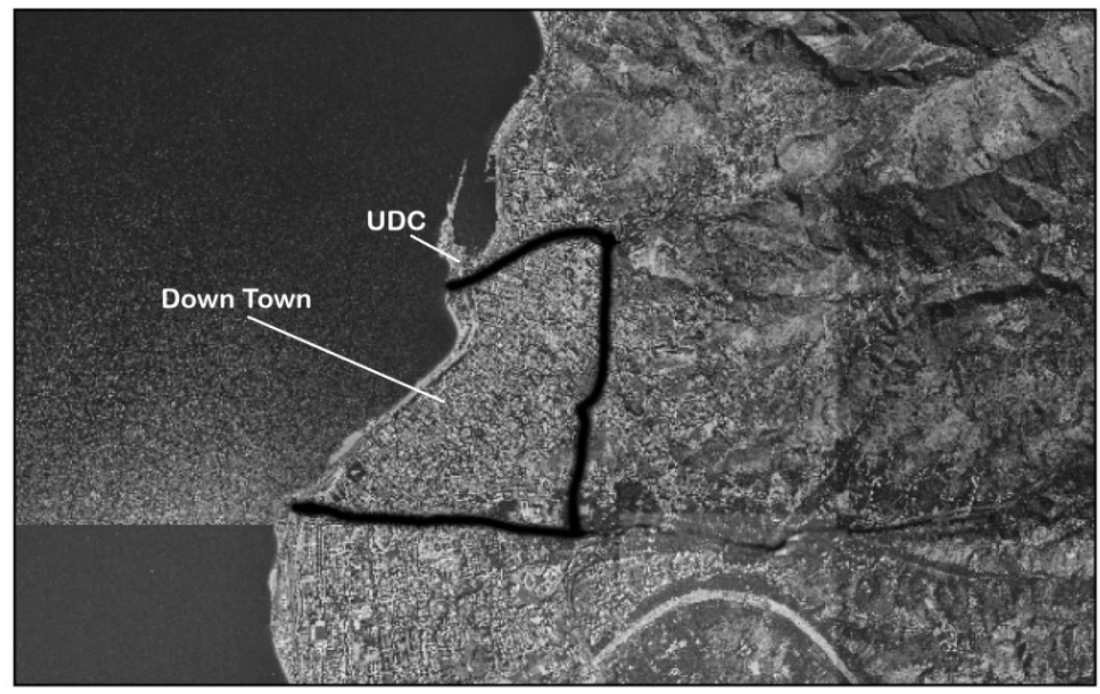

$635,00 \mathrm{~m}$

Figure 1: The center of the city of Reggio Calabria between the two rivers.

Retrieved from: http://www.pcn.minambiente.it/viewer/ accessed March 2015.

\subsection{The port area}

The port area of Reggio Calabria is adjacent to the border, the north side of the old town, Fiumara Annunziata. The coverage of the Fiumara has enabled a road axis connecting the area to the University City. It is served by major transport infrastructure; has direct access from the highway A3 Salerno-Reggio Calabria; from State Road Jonica106. It is easily accessible from the city center on foot and has an internal railway station.

The port area has a mixed function. It assures the link with the city of Messina, the Aeolian Islands and Malta. It is equipped with facilities for freight, 
port lifting and other functions including a marina, the offices of the harbour and a manufactured housing for the fish market.

The Master Plan has destined the area around the port area as building expansion. Over the years, this part of the city was built in an intensive way and today, the volumes built have saturated the available surfaces.

\subsection{The disused railway building}

There is an area (Fig. 2) close to the port of approximately 7,700 sq.m. Within this area, exists a disused building, approximately 800 sq.m., previously used to store goods.

The building was built around 1950, with reinforced concrete structure and double pitch roof. It has a rectangular shape with sides of about 60 meters and 11 meters. One side of the building is equipped with a covered area, bus shelter, of approximately 15 meters by 12 meters.

On the long sides of the building are located two quays. It has 15 accesses, overlooking the quays side. These accesses permit the unloading and loading of goods in the store.

The square that surrounds the building is served by three binary terminals for the parking and unloading of railroad cars; a rail stop directly connected to the port; a rail for the direct discharge on the quay of the warehouse.

This area has more access overlooking on different roads. A gate opens onto the adjacent ramp road linking the area with the ring road of access to the A3 Salerno-Reggio Calabria and the Jonica National Road 106; a further passage connects to the tracks that pass by the station to Lido Harbour Station.

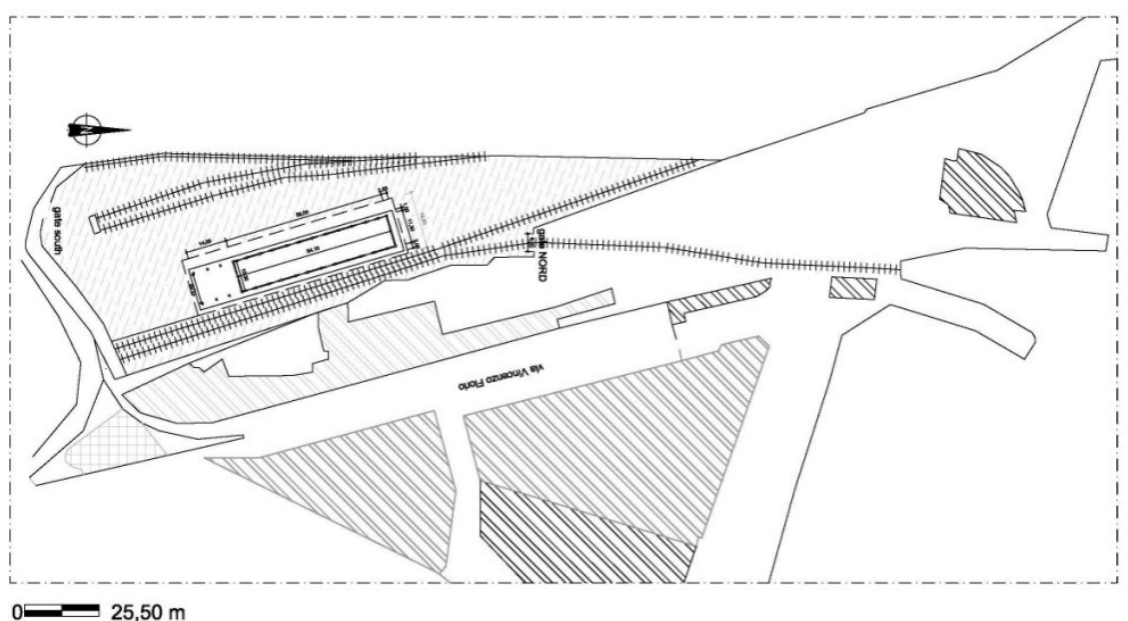

Figure 2: The railways building. Reworking by UDC extract Map Inland Revenue, section Territory, Italy. 


\section{Conclusions}

The EU is rewarding cities that become smart cities. The cities where the integration between infrastructure and services produces sustainable development, improving the quality of life and social wellbeing. The redevelopment of strategic disused sites, contributes significantly to the process of urban transformation, indispensable to reassign a new competitive role, to revive the image of a city in innovated structure, efficient in functions. The attractiveness of an area is complementary to its competitiveness [13].

The use of old disused public buildings allows a balance to be re-established and the healing of waste of land, revitalizing important areas. The city logistics is a proposal within a perspective of smart cities, to make an economically depressed and degraded place, located in a strategic position, in the city of Reggio Calabria productive.

\section{Acknowledgements}

Luciano Amodeo, Paolo D'Agostino, Domenicantonio Lamari and Tiziano Scattarreggia, collaborated to the application as students of the Master of Transportation Engineering, supplied in 2014-2015 at Dipartimento di Ingegneria dell'Informazione, delle Infrastrutture e dell'Energia Sostenibile of Università Mediterranea di Reggio Calabria.

\section{References}

[1] European Commission (1999), European Spatial Development Perspective ESDP-Towards balanced and sustainable development of the territory of the European Union, Office for official publications of the European Communities, Luxembourg, ISBN 92-828-7658-6. http://ec.europa.eu/ regional_policy/source/docoffic/official/reports/pdf/sum_en.pdf

[2] La Greca P., From urban design to regional policies: a new role for planners in Italy; in Martinico F. (a cura di) Ricerca didattica e prassi urbanistica nelle cittá del mediterraneo Ed. Gangemi, Rome Italy, ISBN 978-88-492-2220-3, 2011.

[3] Italian Government, Law 17august 1942, n.1150. Legge Urbanistica 1942. http://www.bosettiegatti.com/ info/norme/ statali/1942_1150.htm

[4] Russo F. \& Musolino G., A unifying modelling framework to simulate the Spatial Economic Transport Interaction process at urban and national scales. Journal of Transport Geography 24, Elsevier, pp. 189-197, 2012.

[5] Las Casas G., Sansone A., Una cultura della pianificazione in un approccio rinnovato alla razionalitá nel piano, in Deplano G. Politiche e strumenti per il recupero urbano, Edicom Edizioni, Monfalcone (GO), ISBN: 978-88-86729-53-5, 2004.

[6] Busacca P., Il racconto del territorio, Gangemi Editori, Roma, 2000.

[7] Faludi A., Planning theory, Oxford, Pergamon Press, 1973. 
[8] Leonori M., Testa P. (a cura di), La città oltre lo sprawl, Italianieuropei, Edizioni Solaris, Roma ISBN 97-89988-66-4, 2013.

[9] European Commission (2012), Communication from the commission smart cities and communities - European Innovation Partnership, 2012.

[10] European Commission (2013), European Innovation Partnership on Smart Cities and Communities, Strategic Implementation Plan, 2013, http://ec.europa.eu/eip/smartcities/files/sip_final_en.pdf

[11] MIT, Smart Cities Group, Cambridge, MA., 2013. http:// smartcities.media.mit.edu/ frameset.html

[12] European Parliament, Mapping Smart Cities in the EU, Directorate general for internal policies, 2014, http://www.europarl.europa.eu/studies (last accessed May 2014).

[13] Russo F., Rindone C., Panuccio P., The process of smart city definition at EU level, WIT Transactions on Ecology and the Environment, Vol. 191, pp. 979-991, WIT Press, Southampton, UK, 2014.

[14] Musolino G., Panuccio P., Planning Instruments In Italy And The UK: Private And Public Spaces For Emergency Events In Urban Areas, Safety and Security Engineering V, WIT Press, Vol.134, pp. 565-574, Southampton, UK, 2013.

[15] Freight Leaders Council (FLC, 2012), Info Quaderno 22 dicembre 2012, Accessibilità, distribuzione urbana e mercato della logistica: un manuale operativo.

[16] ICity Rate (2014), La classifica delle città intelligenti italiane, Ottobre 2014, Edizioni Forum PA-Collana Ricerche. http://creativecommons.org

[17] Russo, F., Vitetta, A., Comi, A., Estimation of target time distribution for agri-food products by road transport. Operations Research/Computer Science Interfaces Series, Vol. 46, pp. 267-283, 2009.

[18] Fallanca C., Critelli G., Taccone A., Umbro M., Mobilità e politiche di riqualificazione urbana sostenibile, in: Marcucci E., Musso E., (a cura di) Sostenibilità, qualità e sicurezza nei sistemi di trasporto e logistica, Franco Angeli, Milano, 2011.

[19] Russo, F., Vitetta, A., Polimeni, A., From single path to Vehicle Routing: The retailer delivery approach. Procedia - Social and Behavioral Sciences, Vol. 2 (3), pp. 6378-6386, 2010.

[20] Polimeni, A., Russo, F., Vitetta, A., Demand and routing models for urban goods movement simulation. European Transport - Trasporti Europei, Vol. 46, pp. 3-23, 2010.

[21] Cirianni, F., Panuccio, P., Rindone C., A comparison of urban planning systems between the UK and Italy: commercial development and city logistic plan, WIT Transactions On The Built Environment, vol 130, pp. 785-796, Southampton, UK, 2013.

[22] Amodeo L., Lamari D., Musolino G., Placido V., Polimeni A., Praticò M. \& A. Vitetta, An ex-ante evaluation of last-mile freight distribution services for city logistics In WIT Transactions on the Built Environment, volume 146, 2015. ISSN: 1746-4498, Digital ISSN: 1743-3509. 
[23] Praticò F.G., Moro A. \& D'Agostino P., An experimental investigation on innovative pavements for city logistics. In WIT Transactions on the Built Environment, Vol.146, 2015. ISSN: 1746-4498, Digital ISSN: 1743-3509.

[24] Gattuso, D., Cassone, G.C., A statistical analysis for micro-simulation of UDC operativity. Procedia Engineering, Vol. 21, pp. 114-124, 2011.

[25] Russo F., Rindone C., D’Agostino P., Lanciano C. \& Scattarreggia T., Long distance freight transport to the provisioning of a city logistics. In WIT Transactions on the Built Environment, volume 146, 2015. ISSN: 1746-4498, Digital ISSN: 1743-3509.

[26] Gattuso D., Cassone G.C., Lanciano C., Placido V. \& M. Praticò. A freight urban distribution center design with micro-simulation support for city logistics. In WIT Transactions on the Built Environment, volume 146, 2015. ISSN: 1746-4498, Digital ISSN: 1743-3509. 